\title{
脱灰象牙質を Implantに応用した際の骨界面に関する形態学的研究
}

\author{
遠藤哲彦

\section{Morphological study concerning the interface of Implants with demineralized dentin}

\author{
Tetsuhiko ENDOH
}

\begin{abstract}
Recently, hydroxyapatite which is made from apatite hydroxide has been clinically used in dental implants. It is known that hydroxyapatite functions as osteoconduction but not as osteoinduction. Thus, we applied demineralized dentin, a material having an effect of osteoinduction, in combination with hydroxyapatite dental implants. The author observed morphologically its mechanism in relation to bone attachment. Thirty mongrel dogs were used in this study. Their 3rd and 4th premolar teeth were extracted. After extraction, the teeth were cleaned by removal of the dental pulp and remnants of periodontal ligaments which remained on the cement surface. The extracted teeth were decalcified using PlankRichlo method for 1 week, and rinsed overnight with distilled running water then sliced $100 \mu \mathrm{m}$ thick in a cryostat. The sliced dentins were implanted with Apaceram $\mathbb{B}$. At 3 days, 1 and, 2 weeks, 1, 3 and 6 months after operation, the experimental dogs were sacrificed and specimens were fixed. The osteoid was observed around the demineralized dentin 3 days after operation. On days 7 and 14 after operation, new bone accumulated around the implant. On day 7, the demineralized dentin was enclosed by new bone. On day 30 , demineralized dentin was resorbed and replaced by new bone with the passage of time. The newly formed bone was found to be ankylosed with the implant.
\end{abstract}

Key words: implant (人工随根), demineralized dentin (脱灰象牙質), bone morphogenetic protein (BMP)（骨形成蛋白）

\section{I. 緒言}

歯の欠損に伴い，その補綴処置として固定性義歯や可 撤性義歯によって機能や審美性などの回復をはかってい、 るが, 前者では隣在曾の切削, 遊離端欠損では不可能で あるといら問題があり, 後者では義歯の維持安定, 装着 感の悪さなどの問題を残している. 近年それらの問題を 補らべく，さまざまな人工歯根が開発され臨床応用に供 されている.これらの人工畨根を Osborn'1)は, 骨との 結合様式により，人工粦根周囲に線維性結合組織が介在

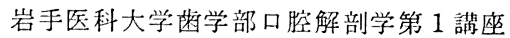

(主任：野坂洋一郎教授)

First Department of Oral Anatomy, School of Dentistry, Iwate Medical University. (Chief: Prof.

Yoh-ichiro Nozaka)

受付日：平成元年11月24日
するものを biotolerant (生体許容性)，じかに骨と接触 するかあるいはごく薄い線維性結合組織が介在するも のを bioinert (生体不活性)，人工歯根周团に形成され る骨と化学的に結合するものを bioactive (生体活性), と分類している. 人工歯根の埋植操作は非常に緎細で, 埋植窩との適合が恶い場合には骨との間に線維性結合組 織が介在し人工歯根の固定が不十分となる。ささらに母林 骨の状態により応用笨囲は限られ，骨梁が粗である場 合，患者が高秢の場合などでは，応用が困難となること が報告されている2)．人工歯根と母床骨とが接するメか ニズムは，生体親和性のきわめて高い生体活性材料て も，母林骨から骨が新生される Osteoconduction（骨层

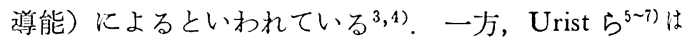
象牙質や骨を塩酸などで脱灰処理することにより，これ が筋肉内や皮下で異所性に骨を形成することを報告し た。これらの骨や象牙質中に存在する物質は骨誘導能を 有し, 不溶性非コラーゲン蛋白で, Bone Morphogenetic 
Protein (BMP) と彼ら惽兄た。

そこで，積極的炕骨を作る骨誘導蛋白 (BMP) を有し ている脱灰象牙質を人工歯根埋植に応用すれば，人工齿 根と母床骨が早期洁合し，人工歯根の固定が十分とな り，さらに埋植が困難と思われる症例飞対しても応用が 拡がると考え，その結合様式と脱灰象牙質の動態を形態 学的観察した。

\section{II. 実験方法および材料}

\section{1. 実験材料}

雑種成犬（30頭，年龄 $2 \sim 3$ 歳，体重 $8 \sim 15 \mathrm{~kg}$ ) を岩 手医科大学崡学部動物舎で, 固形飼料（オリエンタル醉 母工業, 東京) を与兄，1 か月の予備飼亩後，健康状態 であることを確認し実験に供した．なお，実験に供する イヌはロ腔内の清掃として週 1 回ブラッシングおよびス ケーリングを行った.

眖灰象牙質として，ペントバルビタール（DAINABOT 社製 $w / \mathrm{kg}=25 \mathrm{mg}$ ）静脈麻酔下で雑種成犬から左 右両側下領第 3 , 第 4 前曰歯を抜去後, 歯周組織拉よび 歯䯣を機城的俆去し，プランクリロ液にて1週間脱灰 し, 流水で一昼夜水洗, クリオシュタットにて $100 \mu \mathrm{m}$ 厚儿薄切し，生理食塩水中 $\left(4^{\circ} \mathrm{C}\right)$ 飞保存した。眖灰象 牙質の骨誘導能が低下しないよう保存は 3 日以内とし $た^{8)}$.

埋植用人工歯根としては生体活性材料であるアパタイ トセラミックス（旭光学社製アペセラム $\phi=5 \mathrm{~mm}, \mathrm{~L}=$ $15 \mathrm{~mm}$ 製品コード SRT 1550）を用いた，埋植前のX線 写真上で歯槽頂から下䫇管までの長さ，および拔去歯牙 の歯根長より埋植窝を $7 \mathrm{~mm}$ とした，埋植後の咬合力な ぞによる外力を除き，人工歯根を歯槽頂の高さにあわせ るため, 人工歯根をカーボランダム, ペーバーポイント およびンリコンポイントなどで $7 \mathrm{~mm}$ の長さに切削し た. 人工齿根上縁の形状は頓舌方向の歯槽頂の繁曲に合 わせて鞍状に整形した．切削片を除く意味で生理食塩水 にて人工歯根を十分に洗浄した，埋植前に $100 \mu \mathrm{m}$ 厚薄 切象牙質とともに EOG ガス減菌を 2 時間行い埋植前に ガス抜きの意味で減菌生理食塩水中に 30 分間浸漬放置し た.

\section{2. 埋植手術方法}

実験動物の下顎第 3 , 第 4 前曰歯はあらかじめ 3 か月 前に拔去し，肉眼ならびに，X線写真で抜歯窝の治癒を 確認し，同部位に埋植窩を左右 4 か力所設定した，埋植に あたっては，ペントバルビタール $(\mathrm{w} / \mathrm{kg}=25 \mathrm{mg})$ 静脈 麻酔下で，口腔周囲およびロ腔内をビロゾンおよびョー ドで消毒した．その後下顎頓側粘膜を第 2 前曰崡から第 1 大日歯棌及ぶ切開線を設定し, 骨膜に達する切開を加 兄, 骨膜制離子にて粘膜骨膜を剩離して舌側に翻転し骨 面を露出させた。人工歯根と脱灰象牙質を併用して埋植

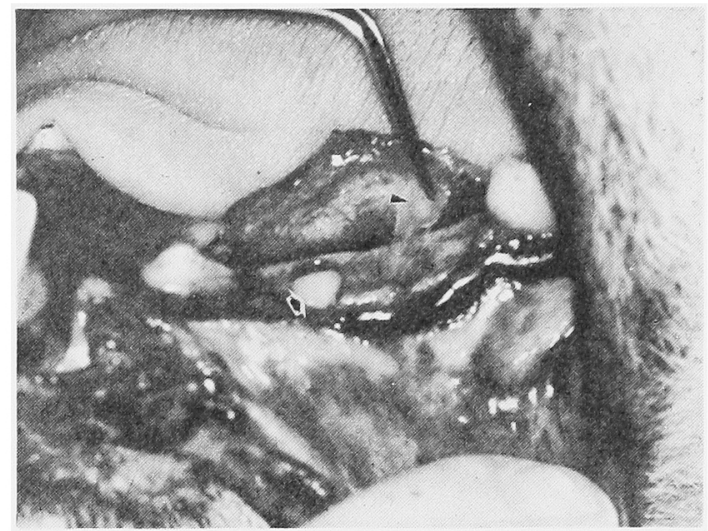

写真 1 埋植简内比 $100 \mu \mathrm{m}$ 厚の脱灰象牙質を窝壁 周囲全周を被うように挿入する。

矢印は埋植した人工菌根を示す。矢頭は脱灰象牙質 を示す。

したすのを笑験群とし，人工歯根のみを埋植したすのを 対照群に設定した。

滅菌生理食塩水注水下にて埋植方向を確認しながら， トレパン（旭光学社製）にて，できるだけ低速回転で切 削した。埋植窩の深さは，7 mm とし円柱状の骨塊をピ ンセット扰よび探針などで取り除いた後フィンガード ライパー(旭光学社製)に手用リーマ(旭光学社製) $\phi 4.6$ $\mathrm{mm} \sim \phi 5.0 \mathrm{~mm}$ を装着して $0.1 \mathrm{~mm}$ ずつ 5 段階で拡大 乙最終 $\phi 5.0 \mathrm{~mm}$ の埋植䈑を形成した，埋植凳の䈑底 は, エンドカット（旭光学社製）飞て整形し，十分止血 させた後埋植窩内の削片は減菌生理食塩水にて洗い流し 除去した。 この左右 4 か所の埋植窝の5ち， 3 か所に $100 \mu \mathrm{m}$ 厚の脱灰象牙質を插入し $\phi 5 \mathrm{~mm}$ の人工歯根 (䞟光学社製)を指压で埋植した，残りの1か所には人 工歯根のみを埋植し，その埋植操作の手順は同様行。 た（写真1)，それぞれ挿入終了後，粘膜骨膜升を戻し て曲収性の CHROMIC 3-0 (日本商事社製)で結節縫 合しョード，ピロゾンでロ腔内を消毒した．埋植終了後 ベンジルペニシリンカリウム（明治製菓 i.M.) 10 万単 位 3 日間計 30 万単位投与した. 理植直後にX線撮影を行 い埋植状熊を確認した。

\section{CMR およびラベリング観察方法}

人工歯根周囲の骨形成, 石灰化, 血管構筑を経時的に 観察するために，埋植期間は 3 日， 1 週間，2 週間， 1 か月，3か月拉よび6か月とした，埋植後の人工歯根拉 よび脱伙象牙質周囲の骨の形成量执よび形成方向を観察 するためにテトラサイクリン（TC（台糖ファイザー株 式会社製 $20 \mathrm{mg} / \mathrm{kg}$ i.V.) とカルセイン (Cal)（和光純 薬株式会社製 $8 \mathrm{mg} / \mathrm{kg}$ i.V.) Kよるラベリングを行い 未脱灰の樹脂包埋標本を作成した，各埋植期間における ラベリングは図1に示すタイムテーブルにより投与を行 った．さらに，人工䨑根周团の血管構築を锳察する目的 


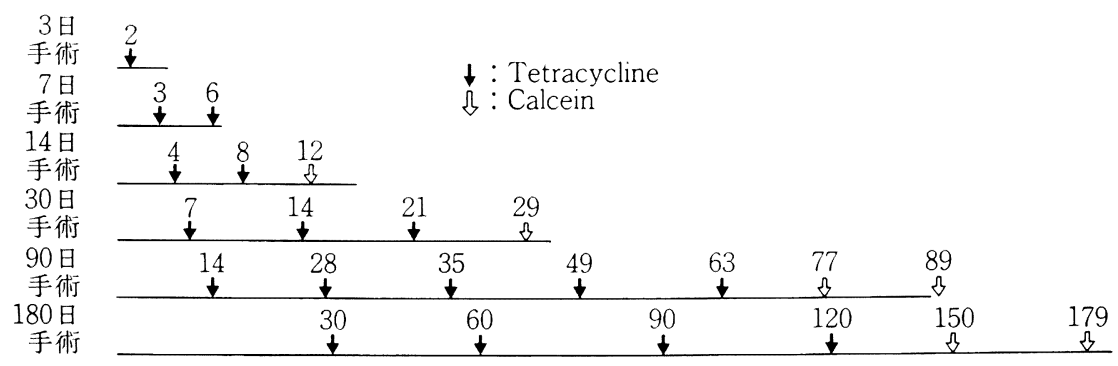

図 1 ラベリングのタイムテーブルを示す.

Tetracycline: $20 \mathrm{mg} / \mathrm{kg}$, Calcein: $8 \mathrm{mg} / \mathrm{kg}$

で，屠殺時に左右の総頸動脈より約 $100 \mathrm{cc}$ 墨汁を注入 した，屠殺後，人工歯根之骨の状態を観察するために下 靧骨を取り出し軟X線（SOFRON TYPE SRO-M 50田中レントゲン製作所）を用い，撮影条件は管電圧 12 $\mathrm{kV}$ ，管電流 $5 \mathrm{~mA}$ ，照射時間 5 分で行った。な打フィル ムには，富士写真フィルム社製 X-RAY FILM ERを 用い, D-19 b で現像時間を 5 分とした。 その後試料は $4 \%$ パラホルムアルデヒドで約 1 か月浸漬固定し, 固定 終了後 1 昼夜水洗, その後アルコール上昇系列にて脱水 し，通法のごとくポリエステル系樹脂（エポラック，日 本触媒化学工業株式会社）で包埋し，次いで，これを雨 槽頂に平行な $500 \mu \mathrm{m}$ 厚の矢状方向切片をバンドソー （SG-350 西国機械製作所）で作製し，スピードラップ （マルトー）にて $100 \mu \mathrm{m}$ 厚まで研磨を施した。，人工米 根周囲の石灰化括よび骨との結合状態を観察するため に, contact-micro-radiogram (CMR) を管電圧 $12 \mathrm{kV}$, 管電流 $5 \mathrm{~mA}$ ，照射時間15分で撮影した。フィルムには EASTMAN KODAK 社製 Kodak Glass plates (Type 649-0) を用い，指定現像を行った。さらに CMR 撮影 後に, 研磨片は無螢光グリセリンで封入し, 落射螢光顕 微鏡 (BH 2-RFL OLYMPUS) で篮光像を観察した。

\section{4. 組織学的観察法}

人工歯根周囲における細胞動態および血管構築を傕察 する目的で, 各観察期間経過後屠殺, 左右総頸動脈上り 約 $100 \mathrm{cc}$ 墨汁注入し，先汇述べたと同一撮影条件で軟 X線撮影した。 その後 $4 \%$ パラホルムアルデヒド1か月 間浸漬固定後 1 昼夜水洗, 固定終了後プランクリク口液 にて約 1 か月間脱灰， $5 \%$ 硫酸ナトリウムにて 1 週間中 和し, アルコール上昇系列で脱水, 通法のごとくセロイ ジン包埋した。ミクロトームにて近遠心に位置する 2 本 の人工歯根が含末れるよ5に矢状方向に $20 \mu \mathrm{m}$ 厚で薄 切し, 切片は H-E 染色を汪どこし光学顕微鏡で観察を 行った.

\section{III. 実 験 結 果}

\section{1. 埋植後 3 日例}

1) 光学顕微鏡像：用いた人工歯根には，上下 2 力所 に $150 \mu \mathrm{m}$ の小突起が存在し, 母床骨々小突起部は非常 に近接し，他の部位は $150 \mu \mathrm{m}$ のスペースが存在した。 実験群では, 脱灰象牙質が人工歯根の全周を被ってい た。脱灰象牙質は弾力性があるため小突起部では薄く 10〜20 $\mu \mathrm{m}$ 程 度に压扁され，スペースの存在部位では $100 \mu \mathrm{m}$ 程度の厚さがあった．脱灰象牙質付近には血管 新生が旺盛で，球形の核および多角形の細胞質を持つ細 胞の集団が観察され，母床骨の骨梁の間は線維性結合組 織で満たされ好中球が散在していた。一部には血餅も認 められた（写真 $2 \mathbf{a}$ ). 脱灰象牙質内には細胞成分はい まだ入り込んでは打らずに象牙細管が認められた。対照 群では，人工歯根と母床骨間に好中球ならびにリンパ球 が多数認められ，血餅が人工歯根と母床骨間の界面に介 在していた（写真 $2 \mathbf{b}$ )。血餅と母床骨の間には細胞分 化は認められないか，埋植窩に面した骨梁表面の細胞は 球形化し骨芽細胞に分化していた（写真 $2 \mathbf{b}$ ).

2 ) 螢光顕微鏡像：埋植後 2 日目に投与した TC のラ ベリングにより, 石灰化に先行する類骨形成の部位に黄 色の螢光が出現した，実験群では，脱灰象牙質そのもの は, 螢光は認められないが，人工歯根と脱圧象牙質の界 面（写真了a）ならび重なりあった脱灰象牙質間治 い䖝光が認められた（写真了 c ). しかし写真了 $\mathbf{a}$ に示 すよらに母床骨には, 強い篮光を示す部位は認められな かった。一方, 対照群における人工歯根周囲では䖝光は 認められず類骨形成は存在しなかった（写真 $2 \mathbf{b}$ ).

3) CMR 像：実験群ならびに対照群に扣いて, 直線 的な埋植窝壁と人工㮀根の小突起部は緊密に接し，それ 以外の部位では，人工歯根と母床骨は離開していた。 こ の間隙に存在する脱灭象牙質は透過像を示し(写真 4 b), 䖝光を示した類骨形成が認められた部位は，大 部分が透過像を示していたが，脱灰象牙質の重なりあへ た間隙には一部不透過像を諗めた（写真 $4 \mathbf{c}$ ). 


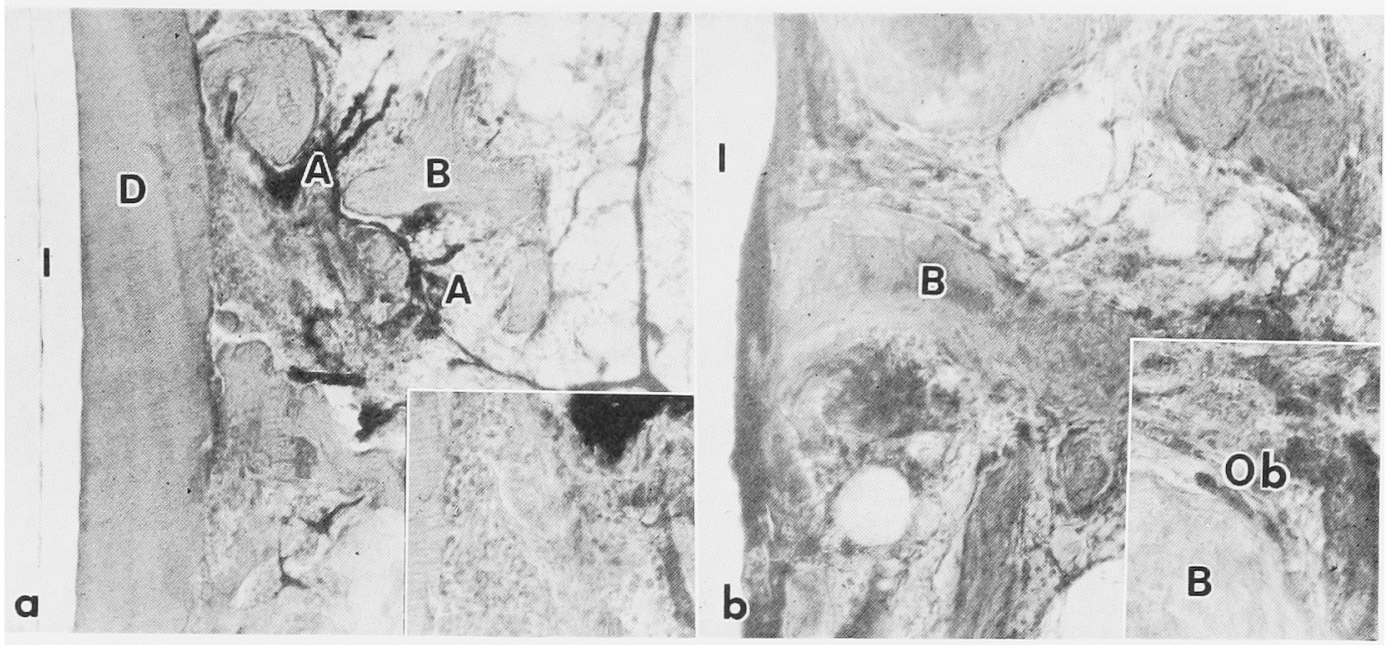

写真 2 埋植 3 日目の組織像 (H-E 染色)

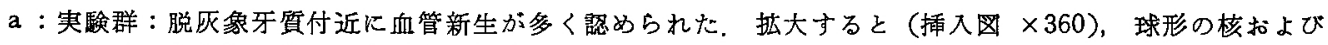

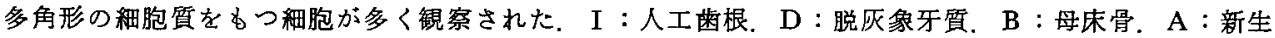
血管 $(\times 180)$.

b：対炤群：人工歯根と母床骨間に血餅が認められた。 その部位を桩大すると（插入図 $\times 400$ )，母床骨表 面に球状の骨芽紐胞が琶められた。Ob：骨芽細胞 $(\times 180)$.

\section{2. 埋植後 1 週間例}

1) 光学顕微鏡像：実験群においては，脱灰象牙質は 人工歯根全周に残存し，3日例で認められた资症性円形 練胞はほとえど消失していた（写真 5 a). 脱灰象牙質 の母床骨側执よび人工歯根側の両側には扁平な細胞が脱 死象牙質に平行に配列していた（写真 5 b). 血餅は质 とえど消失し，線維性結合組織の中には，多数の血管新 生が認められ，一部脱灰象牙質内に血管が侵入してい た．この血管侵入部位では脱灰象牙質が血管由来のマク ロファージや，多核巨細胞により吸収されていた，脱灰 象牙質の母床骨側の表面には球形の核をるちェオジン好 性の細胞質をもつ骨芽細胞が，一列に配列していた（写 真 5 c ). 対照群では，母床骨と人工菡根の間には人工 歯根と平行に配列する線維性結合組織により満たされて いた，その線維性結合組織中には同様に新生血管が存在 し，來床骨の表面には骨茅細胞が認められた（写真 6 ）。

2）螢光像：3日目と6日目にTCを投与したラべリ ングは黄色の線として認められた，実験群において，䖝 光を示す類骨組織により人工歯根と母床骨の間腺は満た されていた（写真7 a). 対照群においては，人工齿根 を取り囲さ母床骨の先端に䖝光が認められ，一部人工歯 根と母床骨の間に点状の䖝光が認められた（写真 $7 \mathbf{b}$ ).

3) CMR 像：実験群に拈いて，3 日例に比べ不透過 性の増した骨が，人工歯根との接触範团を拡大し，埋植 窩壁は凹凸不整を示していた（写真 8 a ），一方，対照 群ではX線不透過性の埋植筒壁は直線状をなし，人工齿
根との間隙には一部点状にX線不透過性を示す部位を認 めた。

\section{3. 埋植後 2 週例}

1) 光学顕微鏡像：人工歯根周囲恃新生骨に取り囲ま れ，形成された骨組織の中に脱灰象牙質は埋没していた (写真 9 a ). 脱灰象牙質の表層には凮板状に形成された 骨が琶められ膜性の化骨が行われたことがうかがわれ， 一部血管の侵入部位では脱灰象牙質の吸収が認められ， その吸収窩に隣接して骨新生が行われていた（写真 9 b). 対照群に扎いては，人工雪根を取り囲さ並行な 線維束が存在していた。この線維束の中に球状をした細 胞塊が出現した。目床骨々線維束の間に形成された線維 性結合組織の中にへマトキシリンに濃染した新生骨が点 在していた.

2）螢光像: 実験群においては，4日目と8日目に TC を静注したラベリングは黄色の線として認められ， 12 日目に投与した Cal は緑色の䖝光線として認められ た. 人工崡根と接した部位には TC の黄色の䖝光のみ 認められた，すなわら，人工歯根と母床骨間の石灰化は 8日目までにほぼ完了していたことを示していた（写真 10b). 一方, 人工齿根周囲に形成された新生骨のハー バース管の血管に接して TC による螢光線が 2 本，そ の内側に Cal の䖝光線が同心円状に配列し，脱灰象牙 質周囲の母床骨を含めて 8 日以降には骨改造が開始して いることがらかがわれた（写真 10b). 対照群において は，4日目と8 日目にラベリングした TCの䖝光線はリ 


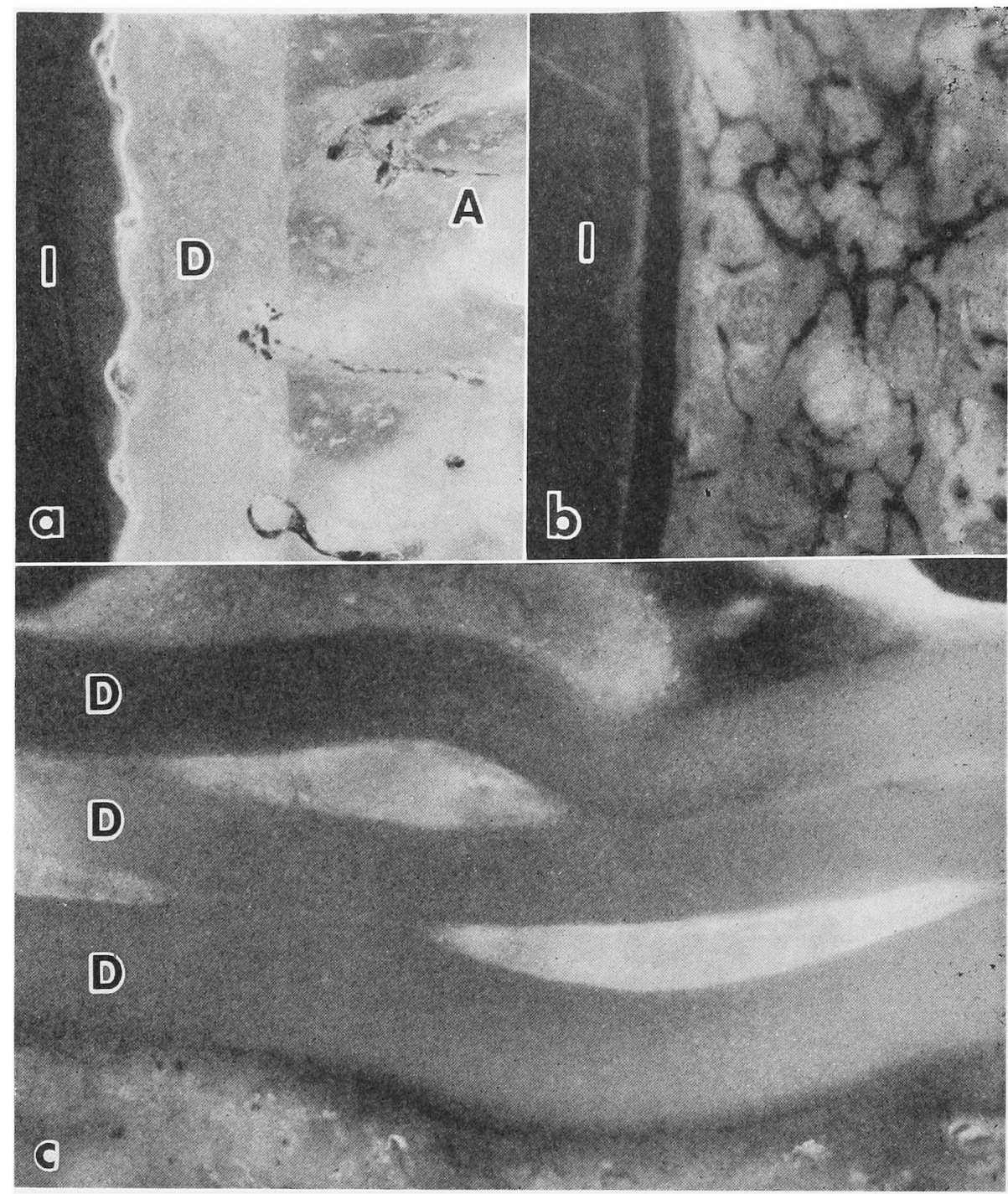

写真 3 埋植 3 日目の螢光像

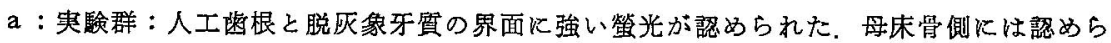
れない $(\times 300)$.

b : 対照群 : 人工歯根周囲の母床骨にはハーバース管内を除いて螢光は悐められない $(\times 300)$.

c：実験群：脱灰象牙質の重なり合った間隙に強い螢光を示す $(\times 600)$.

ング状に島を形成し，さらにこの管光線の人工歯根側に は，点状に Cal の緑色の螢光線が認められ，人工齿根 と接していた（写真 $10 \mathbf{c}, \mathbf{d}$ ).

3） $\mathrm{CMR}$ 像：哭験群の人工橉根周囲に認められる新 生骨のX線透過性は母梋骨とほえど同程度となり骨梁 の太さは増し，人工霜根と接合している範团も 1 週例よ りも增加していた。 また，人工歯根之骨組織の間でX線 透過珄を示す間隙は，その幅を脱灰象牙質の厚さに比べ
ると，狭くなってきていた，眖灰象牙質が吸収され，そ の部位に新生骨が添加され石灰化が進行していた，写真 10bで示した人工崡根表面の 4 日目に TCでラベリンク された部位はX線不透過性を示していた（写真 11a， b). 対照群に扔いては，リング状に TCの䖝光が島を 形成した部分はX線不透過性を示したが，母床骨に比べ ると黑化度が強く，黑点状の骨小窩が多数認められた， 点状にラベリングされていた Cal の緑色の蚪光が恐め 


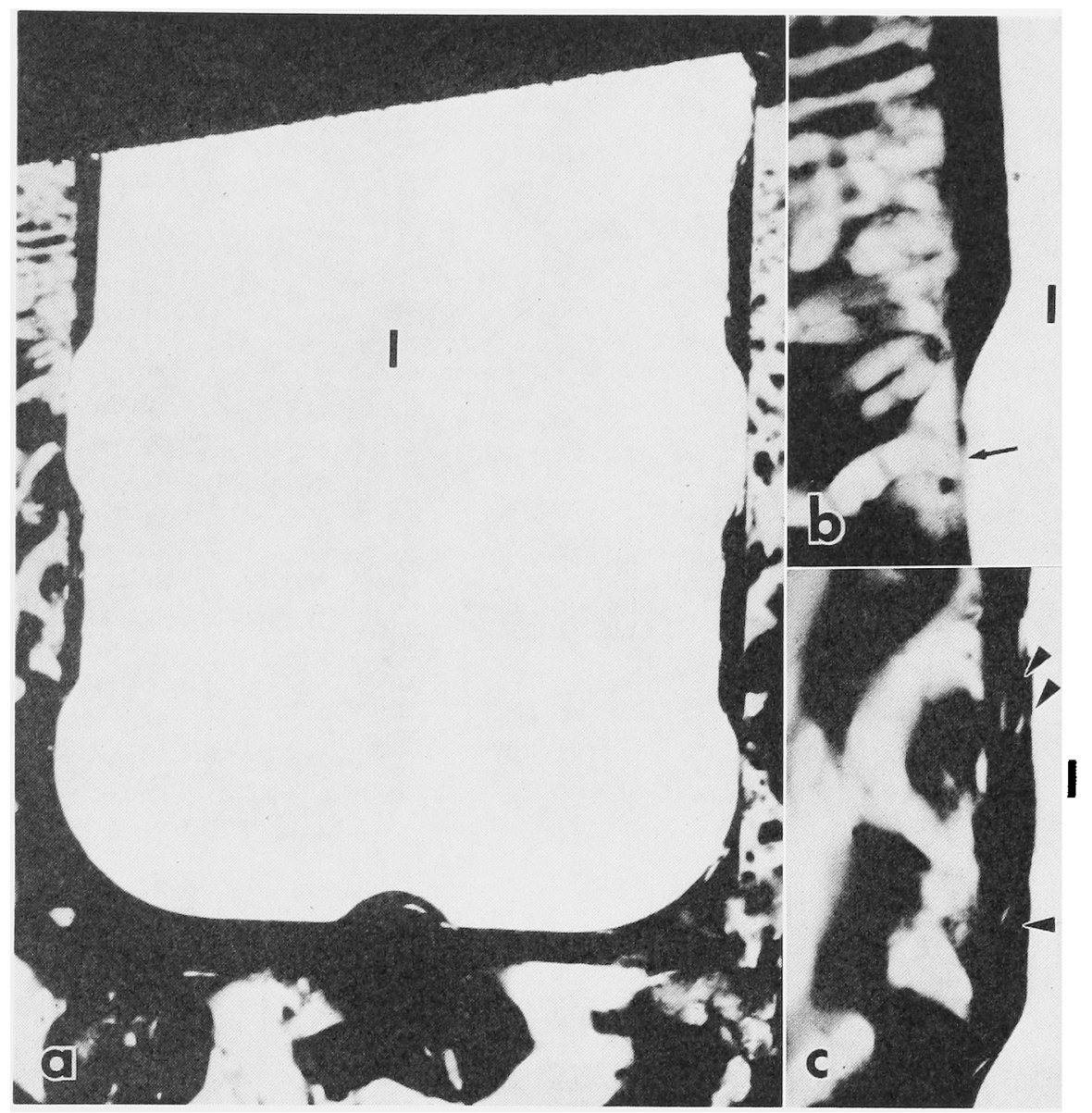

写真 4 埋植 3 日目の実験群の CMR 像

a：埋植窝は直線状をなしている，脱灰象牙質はX線透過性を示す $(\times 8.5)$.

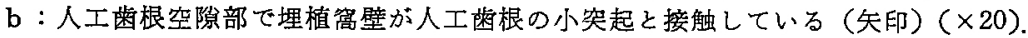

c：人工歯根との間隙に点状のX線不透過性を示す部位も認められた（矢印） $(\times 20)$.

られた部位はX線透過性が強く，未石灰化像を示した。

\section{4. 埋植後 1 か月例}

1) 光学顕徽鏡像 : 実験群に括いては, 人工齿根周团 の骨は骨細胞の配列，染色性は母床督と差がなくな り，二次オステォンを形成し人工歯根は骨性癒着を示し て扣り線維性結合組織の介在は忹とんど認められなかっ た（写真 $12 \mathbf{a}$ )。脱灰象牙質は，ほとんど吸収され 0.1 $\mathrm{mm}$ 程度の小片が骨中に埋没していた，対象群に和いて は人工歯根との界面に形成された新生骨の骨細胞は骨小 腔が広く，胞体子円形を示していた（写真 $12 \mathbf{b}$ ).

2）篮光像：人工歯根表面は7日目，14日目，21日目 にラベリングしたTCの黄色のラインが認められ，血管 を含むオステオンの内面や骨䯣膑側には29日目にラベリ ングした Cal の緑色のラインが認められた（写真 13a ），脱灰象牙質はほとんど吸収されていたが埋植窩
底部に残存が認められるものも市った。この脱灰象牙筫 に出現する䖝光線は脱灰象牙質表層より Cal TC TC TC Cal と配列していることより骨形成は脱灰象牙質の 母床骨側に起こり，さらに骨形成の進行に伴って脱灰象 牙質は吸取され，そこに，骨が再添加し，新生と吸收 をくりかえしながら骨を形成していることがわかった (写真 $13 \mathrm{c}$ )，対照群においては䖝光線の幅は奏験群と ほぼ同じで，一次オステオンが，非常に明瞭で29日目の 粶色の螢光線が 人工宷根と接していた（写真 $13 \mathbf{b}, \mathbf{d}$ ).

3）CMR 像：実験群の人工齿根周囲の骨梁の不透過 度は增し，ほとんど母床骨と同程度を示していた。䖝光 像に和いて7，14，21 日目にラベリングされた部位は不 透過像を示し同部の石灰化が進行していることがわかっ た（写真 $14 \mathbf{a}$ ). 対照群では垁験群に比べ，ハーバース 管が太く $25 \mu \mathrm{m}$ 前後であった。 さらに，人工歯根表面 


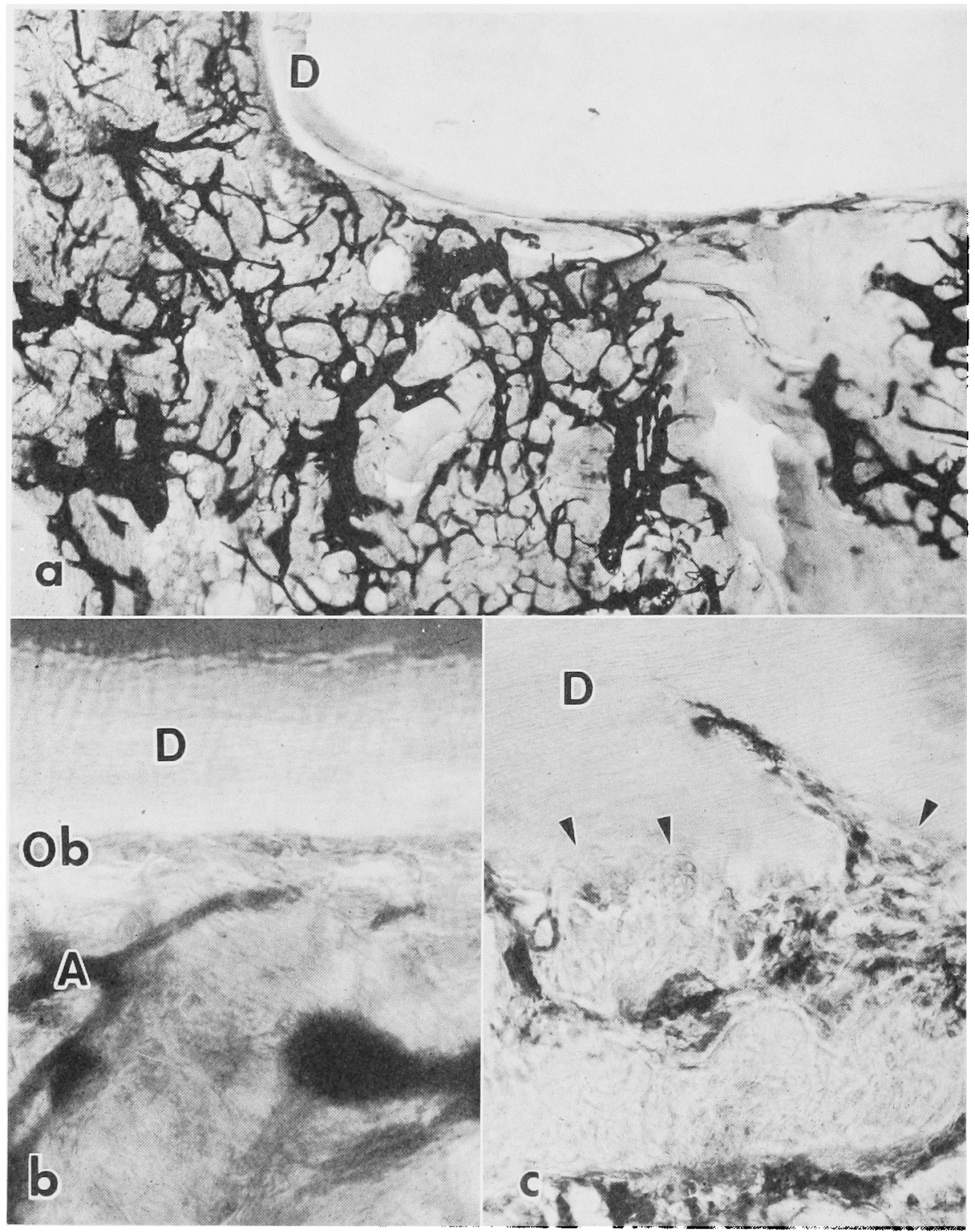

写真 5 埋植 1 週間目の実験群の組織像 (H-E 染色)

a：脱可象牙質周团には線稚性結合組織の存在が認められた $(x 60)$.

$\mathrm{b}$ : 同部位の执大像：脱灰像牙質に沿って球形の核をるつェオジン好性の骨芽勫胞が一列 に配列している $(\times 300)$.

c：脱灰象牙質表面には吸収像（矢頭）が出現していた $(\times 600)$.

飞接して 20〜30 $\mu \mathrm{m}$ の幅に透過性が 良い新生骨が介在 していた（写直 14 b).

\section{5. 埋植後 3 か月例}

1）光学顕徽鏡像：実軻群における人工齿根周囲の脱 灰象牙質はほとんどが吸収され，吸収されず残存した脱 灰象牙質は新生骨内に埋没しており，骨芽細胞が脱灰象
牙質に沿って1列に配列し，骨基質は，母床骨側で層状 に形成され膜性の化骨像を示していた，層板状の石灭化 部位の厚さは1か月より厚くなり 15〜20 $\mu \mathrm{m}$ を示した

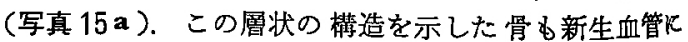
より数か所で分断され，骨改造が血管の侵入に伴って進 行していた（写真 $15 \mathbf{b}$ ). 対照群沈おいても人工歯根周 


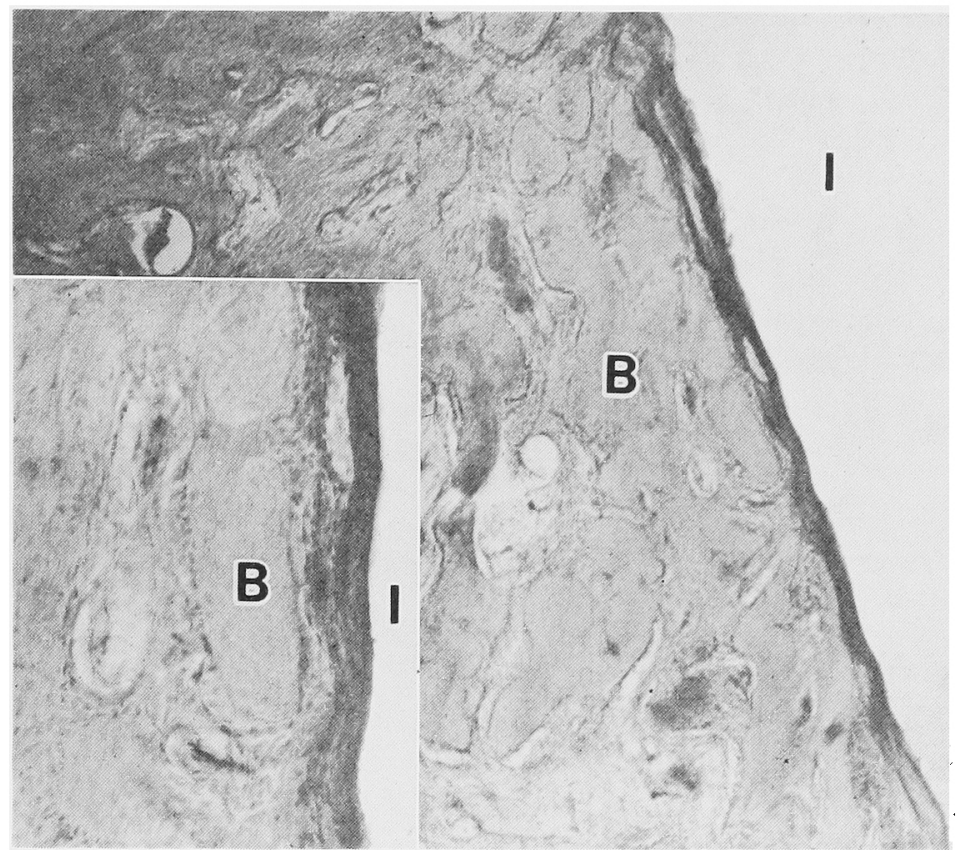

写真 6 埋植 1 週間目の対炤群の組織像 (H-E 染色)

人工歯根と母朱骨の間には線雉性結合組織が介在している。母床骨の表面に は咀芽細胞の增生が認められた（㧴入写真 $\times 175 ）(\times 72)$.

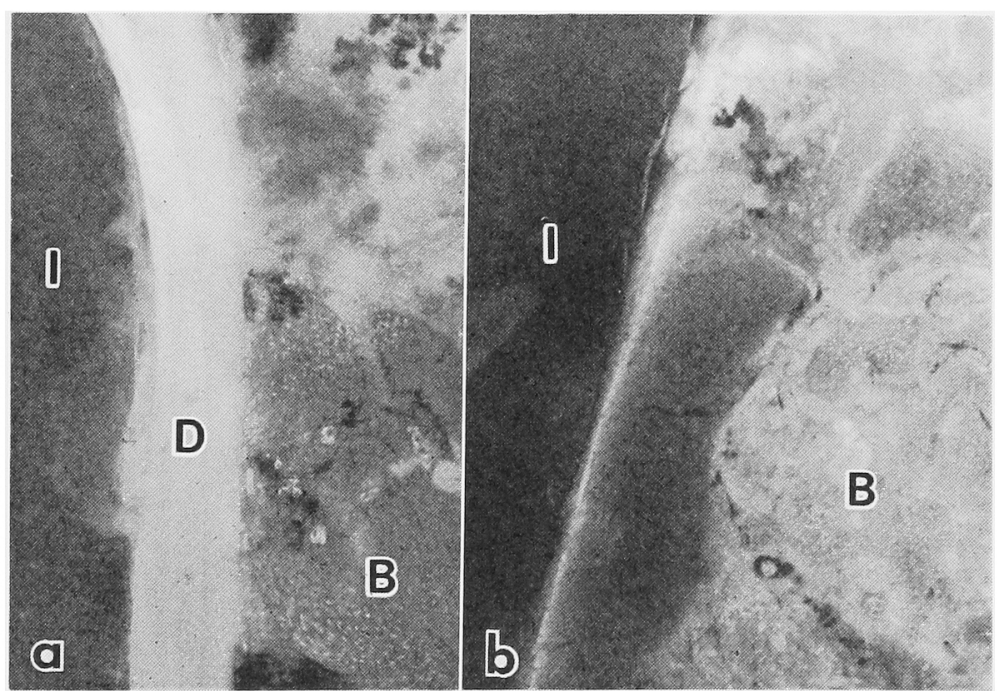

写真 7 埋植 1 週間目の螢光像

a : 実験群 : 脱灰象牙質と人工根の界面に螢光線を認める $(\times 145)$.

b : 対昭群 : 一部床骨表層に螢光線が認めれる (×145).

团は汪とんど新生骨で被われ，人工歯根表面に直角に侵 入した血管が人工歯根表面まで到達し，骨改造が進行し ていた.
6. 埋植後 6 か月例

1）光学顕微鏡像：対照群，実験群ともに人工歯根之 骨組織の界面に線維性結合組織の介在は認められず人工 
歯根全周を基礎層板状の骨が和和っていた，血管は人工 歯根の表面にまで伸展していた，この血管を中心に同心 円状に骨細胞が配列したハーバース管を形成し，骨改造 が盛んに行われていた（写真 16）.

2) CMR 像：埋植後 6 か月経過した CMR 像では事 験群扣よび対象群共に，人工齿根之母停は完全に接合 しており骨性癋着を示していた，形成された新生骨のX 線不透過性は，母床骨と比べて差は認められなかった (写真 17).

\section{IV. 考察}

人工歯根は材料学的には，有機材料である $\mathrm{PMMA}^{3 \sim}$

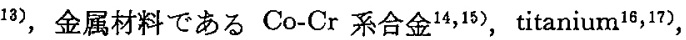
ceramic 材料であるアルミナ18 20)，リン酸カルシウム系 化合物 21 24) ばがあげられるが，これらを Osborn ${ }^{12}$ は，骨との結合様式により，生体許容性，生体不活性， 生体活性，と大別している。現在歯科臨床で広く用いら れているアパタイト・セラミックスは生体活性材料に分 類され，積極的に骨性痣着を目指すものである．骨と人 工歯根の間に線維性結合組織がミ在することは異物に対 する生体反応で，最終的には脱落することが報告されて いる ${ }^{25 \sim 28)}$ ，骨性癒着を阻害する原因としては，物理的な 人工歯根の動摇があげられている ${ }^{29,30)}$. そこで人工雪根 と埋植窩が適合し埋植直後の動摇を防止する必要があ る，さらに適合が良好であれば，骨新生の距離を短くす
ることが可能となる。【かし材料学的には生体活性材料 は骨誘導能を有していない,4) これらの欠点を補ら意 味で, 弾力性を有し，さらに骨誘導能があるといわれて いる脱灰象牙質を，人工歯根の初期固定に応用した。

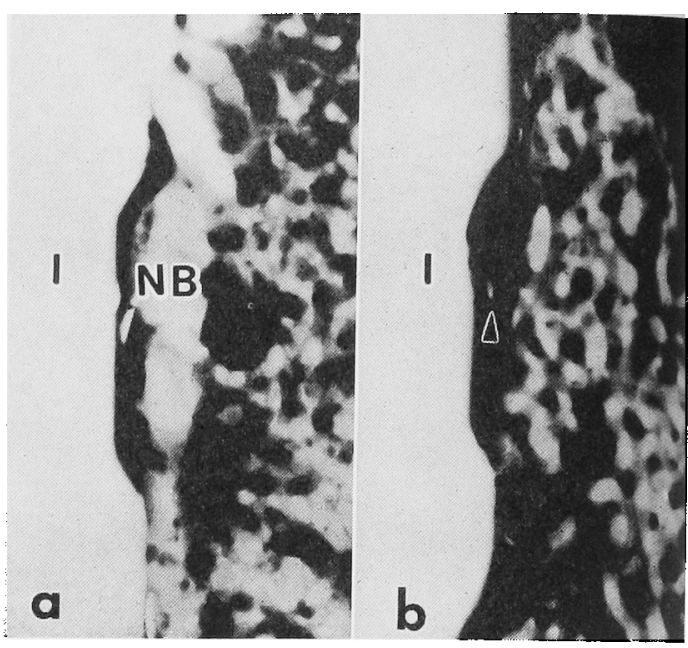

写真 8 埋植 1 週間目の CMR 像

a : 実驗群：埋植窩は凹凸不整をなし，アンダーカ ット部へ新生骨が入り边んでいる像が認められ た. NB : 新生骨 $(\times 27)$

b : 対照群 : 埋植浻壁は直線状をなし，間隙に点状 のX線不透過像が認められる (知頭) $(\times 27)$.

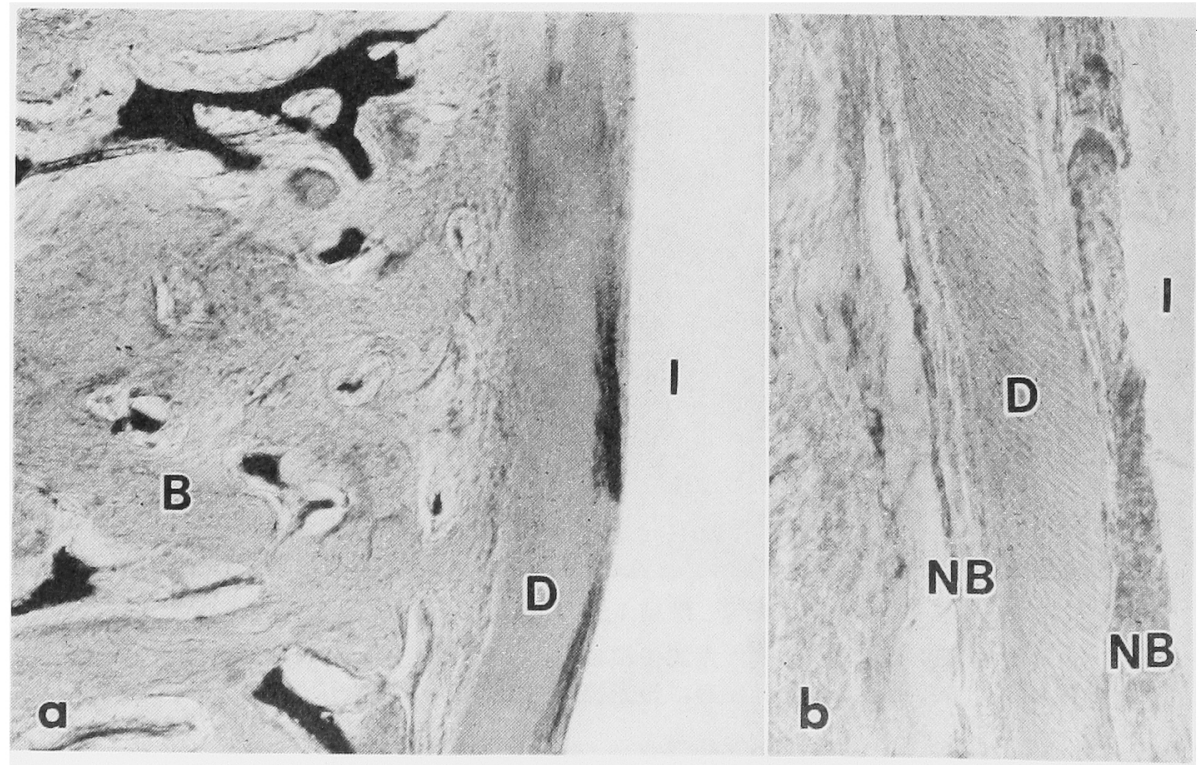

写真 9 埋植 2 㥜間目の实験群の組瀻 (H-E 染色)

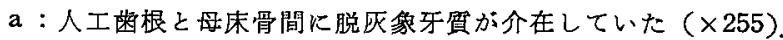

$\mathrm{b}$ : $\mathrm{a}$ の执大：脱灰象牙質の表瓷に層板状の骨が形成されていた $(\times 500)$. 

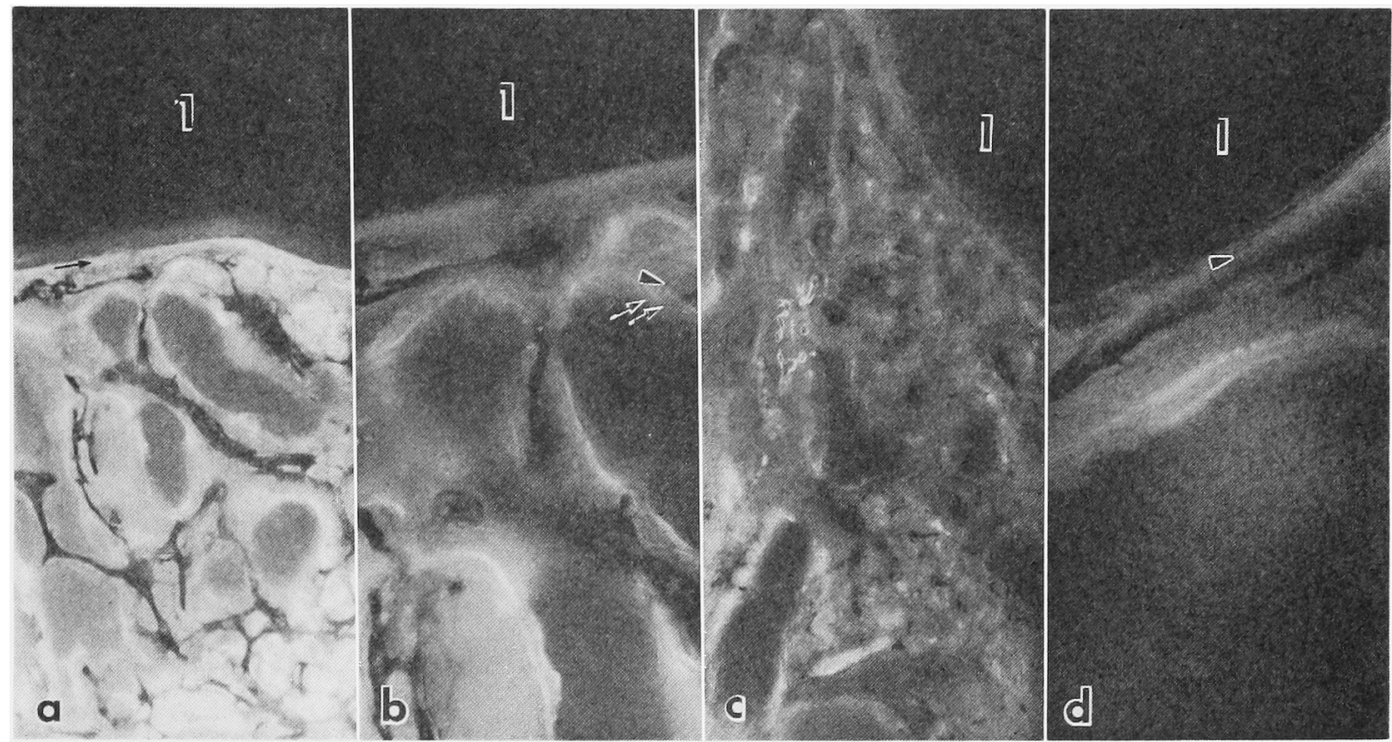

写真 10 埋植 2 週間目の螢光像

a : 実験群：実験 8 日目に投与した黄色の螢光線（矢印）が人工歯根に接して認められた $(\times 116)$.

b : 実験群：ハーバース管には 4 日目と 8 日目に投与した黄色の螢光線（矢印），さらにその内側には 12 日 目に投与した緑色の螢光線（矢頭）が，同心円状涊められる $(\times 290)$.

c：对炤群：写真bと同様にハーハース管に，同心円状の螢光線が見られる $(\times 290)$.

$\mathrm{d}$ ：対炤群：人工歯根に接して12日目に投与した緑色の䖝光線（矢頭）が認められる（×116）.

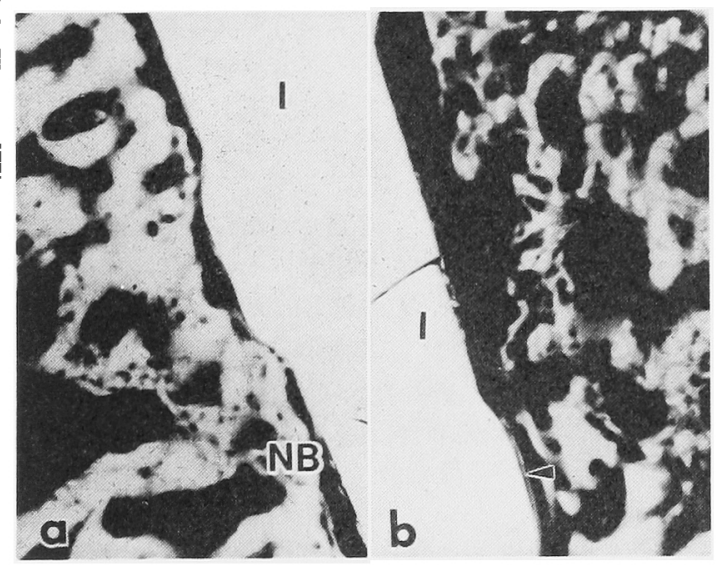

写真 11 埋植 2 週間目の CMR 像

$\mathrm{a}$ : 実験群 : 写真 10-bで螢光を示した部位はX線 不透過性を示した $(\times 23)$.

b : 対照群：人工䅈根と新生骨が接していた（矢 頭) $(\times 23)$.

骨誘導に関しては，1930 年 Huggins ${ }^{31)}$ がイヌ膀脂粘 膜を腹筇内に埋植し，骨形成を観察したことより始ま る. その後Urist $5^{5 \sim 7}$ は，脱灭凍結乾燥骨を筋肉内に 埋植すると，末分化な間葉細胞が骨芽細胞へ分化し骨を
形成する骨誘導能があると報告している，この BMP に ついて，近年各種動物の骨基質中や骨肉腫からの精製や アミノ酸分析扣よび分子量の同定などが行われてい る32 38). しかしいまだ不明の点が多く，精製した BMP 単味の in vivo に和ける応用は十分な骨形成を見るに至 っていない、これは未分化間葉系細胞から骨芽細胞への 分化をらながす BMP の定着性が悪く, BMP の流出が 原因といわれている，そこで in vivo においてはュラー ゲンゲルなどの担体が必要といわれている影 その点脱 灰骨や脱爽象牙質では，BMP の定着といら条件を十分 に満たしており，in vivoで骨形成が起きたと多数報告さ れている40〜33)

実験群では埋植 3 日目で, TC の沈着した螢光像とし て類骨形成が母床骨側と脱灰象牙質側の自方から始ま口 ていた．しかし細胞の分化，增殖がまだ認められない人 工歯根と脱灰象牙質の間腺への沈着はコラーゲン線維に 直接カルシウムが沈着したと考えられる，しかし対照群 では類骨形成は諗められなかった。そこで，このよ5な 初期には BMP 以外の細胞外基質の関与も考えられる。 埋植 1 週間目に至ると実験群においては，母床骨と離れ た脱灭象牙質に沿って骨芽細胞が 1 列に配列し，骨基質 を形成していた。しかし対照群では，人工齿根と母床骨 の界面に線維性結合組織が介在し，骨芽細胞は人工宷根 と離れた母床骨に接して存在していた。 


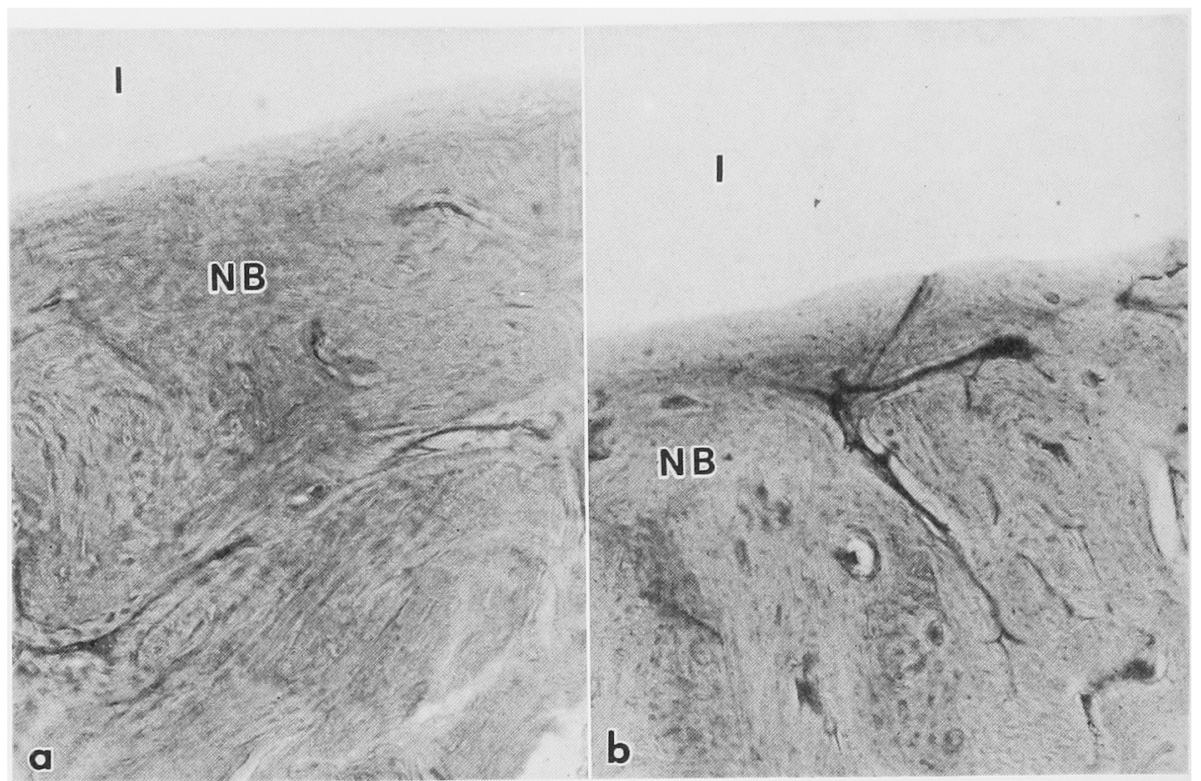

写直 12 埋植 1 か月目の組織像 (H-E 染色)

a : 実験群：人工蒾根と層板構造の明瞭な骨は直接結合している $(\times 390)$.

$\mathrm{b}$ ：対照群：人工蔽根に接した新生骨の骨小腔は拢大していた（×195）.

2 週間目の実験群における螢光所見では，8 日目に投 与したTCの管光線が，人工雪根に接して認められ，対 照群では 12 日目に投与した Cal の䖝光線が，人工歯根 に接して認められた，以上のことより脱死象牙質は，骨 誘導能を有し，人工歯根周团の間葉系細胞を骨芽細胞に 分化させ，骨形成を対照群より早く発現させると考兄 られる。また埋植 1 か月目における䖝光所見で，各ラべ リングの螢光線相互の幅が実験群と対照群でほとんど差 が認められなかったことより，実験群と対照群での骨形 成の速度は，汪とんど変わらないと考える，つまり実験 群と対照群での人工歯根周囲の骨形成の差は，その開始 時期の違いであり，石灰化速度の差ではないことがわか った。 このことは, CMR 像においても，1 週間目の実験 群では 3 日目投与した TC でラベルされた類骨が不透過 性を示し石灰化が進行していたし， 2 週間目の対照群で は，4 日目に投与した TC でラベルされた部分が不透過 性を示すことより，石灰化の程度にも差異のないことが 示された，埋㥀 1 か月目までは骨新生が盛えに起こり， 以後は，血管新生に伴い骨改造が起こる，そして埋植 3 か月目以降の実験群，対照群の間には大きな違いは認め られなかった，脱灰象牙質は骨形成を促すが，同時に吸 収される。このことは，埋植 1 週間目から，血管新生 と共に開始し，埋植 3 か月を経ると活とんと吸収され， 6か月経過すると完全に吸収され，新生骨と直さ換わっ ていた。これはラット大腿骨の脱圧粉を罰骨に埋植する と，脱灰骨粉は完全に吸収され骨組織に置換されたとい
ら井上ら ${ }^{44)}$ の報告と一致している．插入した脱灰象牙質 は異物之考兄られ，将来的には骨と置換することが望ま しい，一般に，骨誘導物質による骨形成は軟骨性化骨と いわれている ${ }^{32 \sim 38)}$. しかもこの化骨量は先に形成された 軟骨の70〜80\%であるといわれている8 。 しかし，軟骨 性化骨では人工歯根と骨の界面に軟骨が介在し，骨性诙 着を妨げる。

著者は予借実験として，さまざまな脱灰条件のイヌ象 牙質をラット腹直筋内に埋植した，その結果，プランク リク口液で 1 週間 $\left(4^{\circ} \mathrm{C}\right)$ 脱灰した象牙質は, 埋植後 10 日経過すると骨芽細胞による骨形成がみられ，骨形成に さきだち軟骨形成は認められない瞙性の化骨であっ た ${ }^{45)}$ 。この結果より脱灰象牙質は，人工歯根と併用すれ ば効力を発揮すると考えた。

今回, 実験群に括いて, 骨新生の形成過程は，埋植 1 週間目で脱灰象牙質に接して骨芽細胞が 1 列に配列し, 埋植 2 週間目で数層の骨芽細胞が配列し，新生骨が層板 状に形成される膜性の化骨の梯相を呈していた，脱乍象 牙質に上る骨誘導能に関する研究で，酸素供給が十分て あれば，間葉細胞から骨芽細胞に直接分化するといら報 告もある ${ }^{34)}$ また Bassett ${ }^{48)}$ は，未分化の間葉細胞を培 盖し好気的条件で圧力を加光ると骨形成が，嫌気的条件 で王力を加えると軟骨が形成されると報告している，骨 形成には酸素供給すなわち，血液供給が重要であること が示唆される。

埋植後 1 週間目に，人工雪根周囲のアンダーカット部 


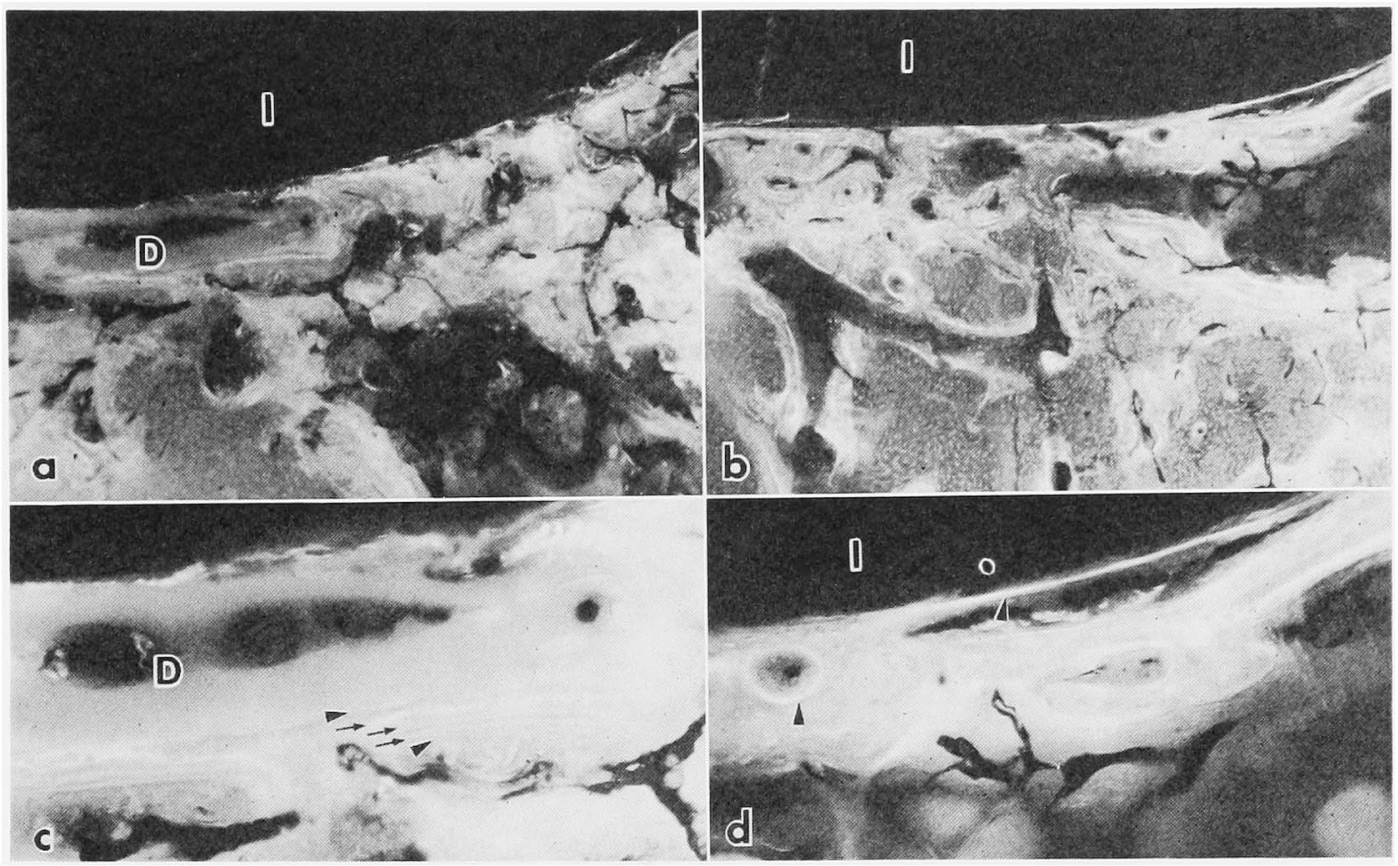

写真 13 埋植 1 か月目の螢光像

$\mathrm{a}:$ 実験群：一部脱灭象牙質が新生骨内に残存していた $(\times 470)$.

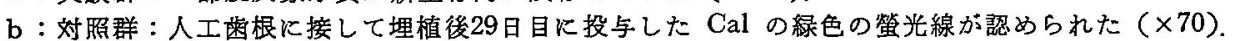

$\mathrm{c}$ ：実験群の拻大像：脱灰象牙質飞接して䖝光線が認められ， Cal (知頭). TC (矢印). TC (矢印). TC (矢印). Cal (矢頭)。と配列していた $(\times 755)$.

$\mathrm{d}$ ：対照群の扰大像：ハーバース管最内側と人工歯根とに接して Cal の緑色の螢光線 (矢頭) が認められた $(\times 355)$.

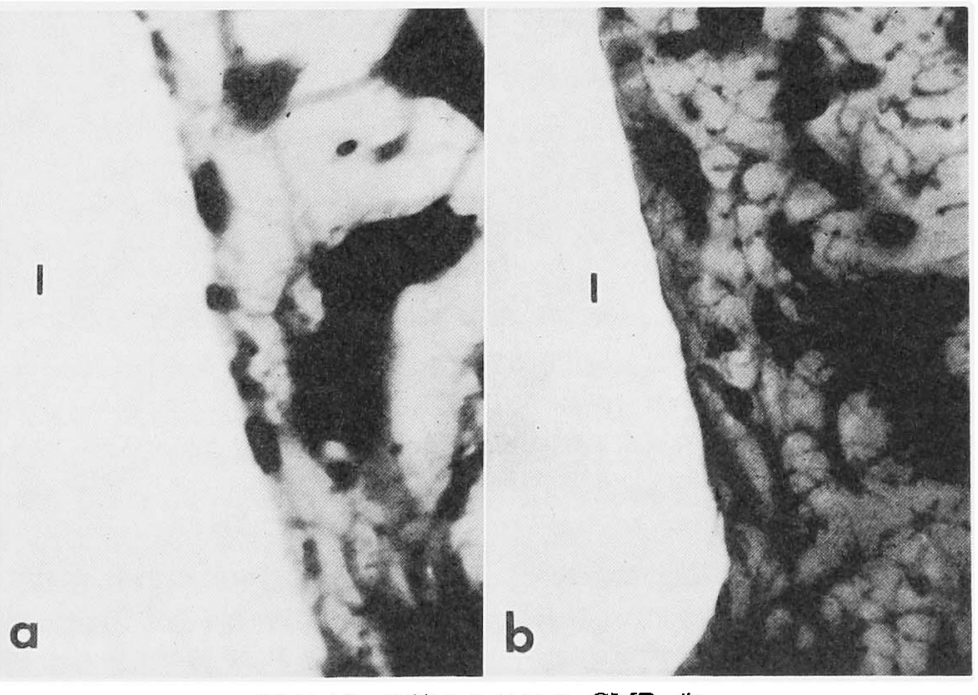

写真 14 埋植 1 か月目の CMR 像

$\mathrm{a} ：$ 実験群：人工歯根と骨は直接接し，X線不透過性は母床骨と差はな い $(\times 28)$.

$\mathrm{b}$ ：対照群：ハーバース管は实験群と比較して太い $(\times 28)$. 


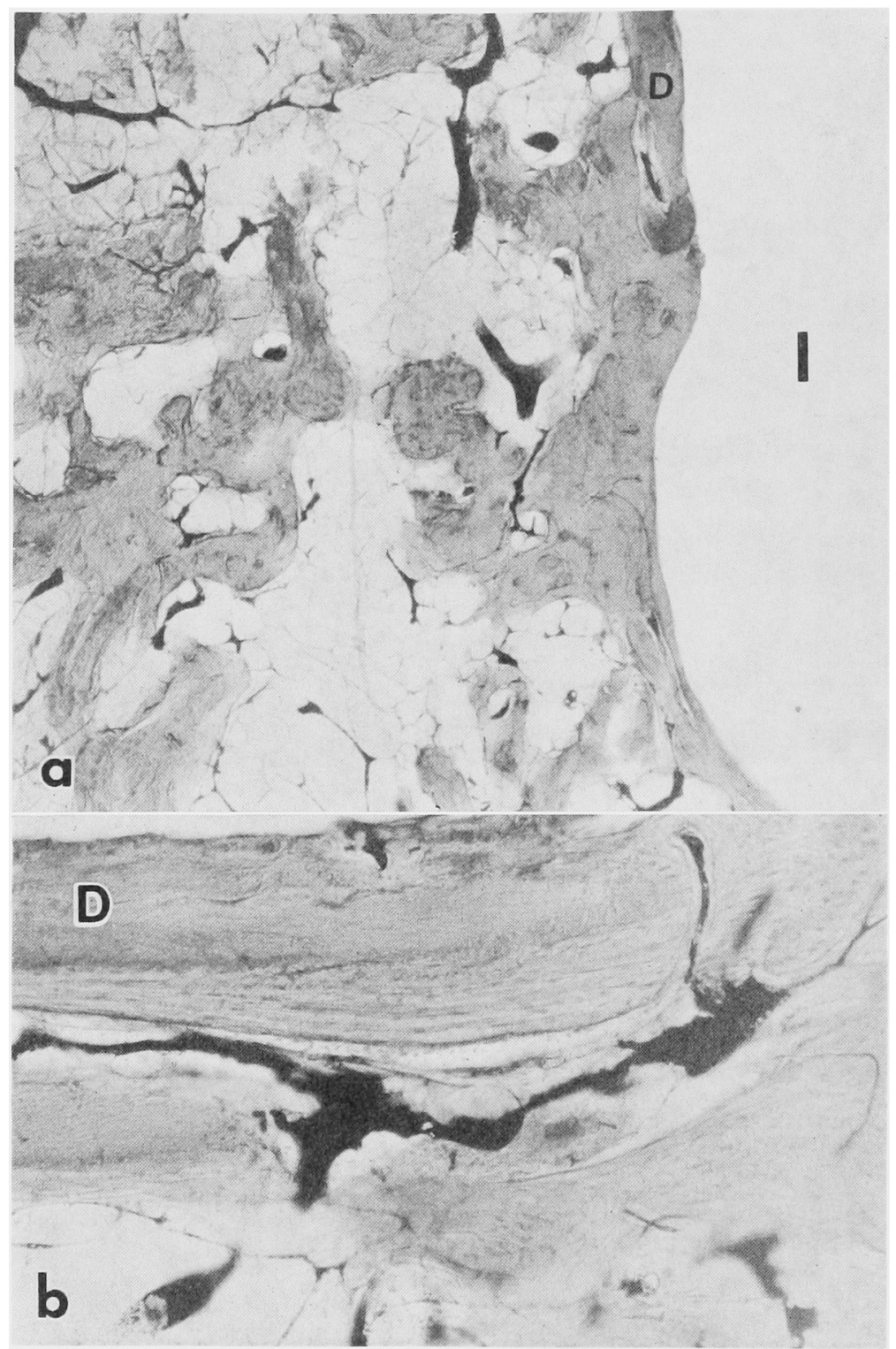

写真 15 埋植 3 か月目の実験群の組織像 (H-E 染色)

$\mathrm{a}$ : 脱灰像牙質の一部が残存しているのが琶められた $(\times 73)$.

$\mathrm{b}$ : 残存している脱灰象牙質に接して骨が層板状に形成されていた，新 生血管が侵入している像が認められた $(\times 73)$.

には新生血管が多数認められる，この部位は埋植 1 か月 目になると新生骨が㬝状に形成されるよらになり，新生 血管は整理されハーバース管として新生骨内に存在す る。すなわち，埋植直後から新生骨が成熟する埋植 1 か 月目までの早期に，血液供秴が十分に行われ，人工歯根周 团の酸素分压が高まっていれば，膜性の化骨が生ずると 類推される．また,Urist ら $47 \sim 50)$ はMP 単独では水に
可溶性で，血清中につ水に存在し，分子量 14,000の Matrix Gla Protein (MGP) と結合 してはじあ水に不 溶性となり，BMP は骨組穖内で MGPを仲介として， コラーゲンと結合して局在していると述べている，豊富 な 血管分布は高い酸素分匤のみならず，BMP の供給の 上からも，骨形成に重要と思われる。

脱灰象牙質は血栟の存在する間隙を埋める役割を果た 


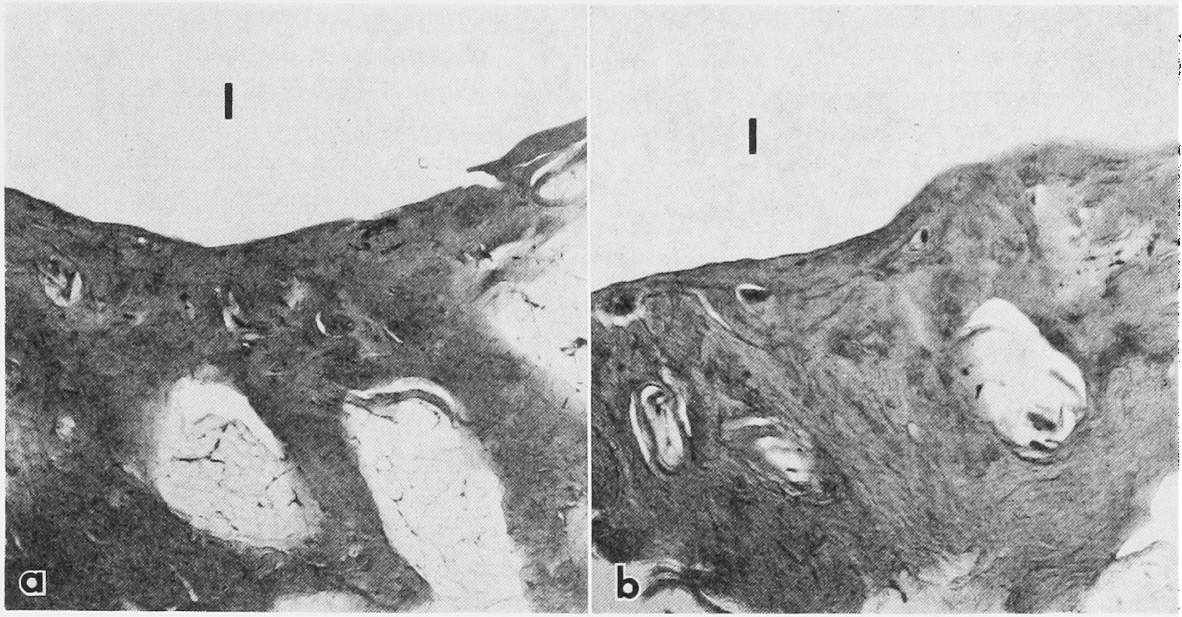

写真 16 埋植 6 加目の組織像 (H-E 染色)

$a$ : 英駼群, $b$ : 対炤群 $(\times 195)$

埋植 6 か月を経過すると実駼群，対照群，とも飞骨と直接接する骨性瘾着の像を珰めた。

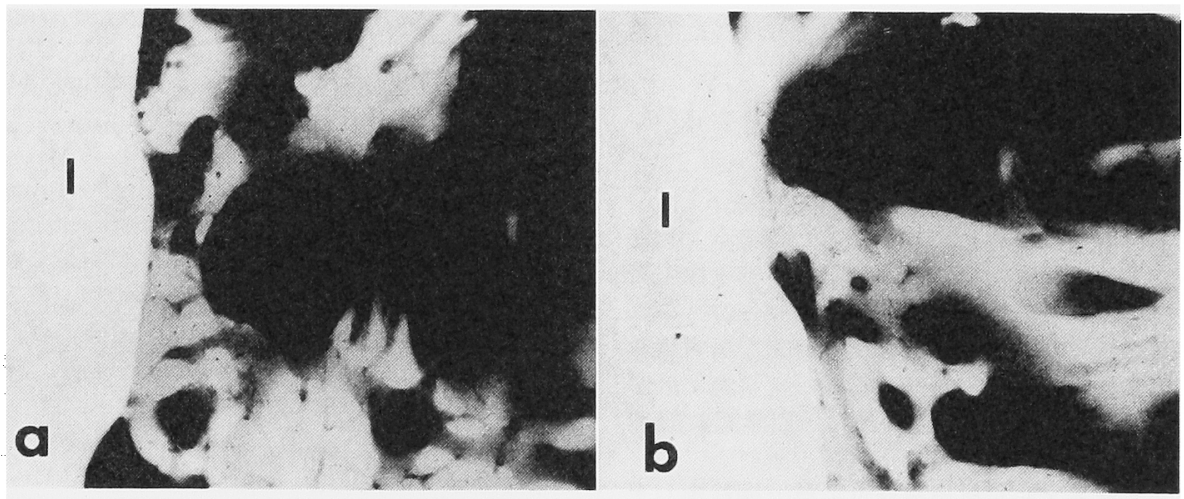

写真 17 埋植 6 和月目の CMR 像

$a$ : 実験群, b : 対象群 $(\times 25)$

埋植 6 か月目の CMR 像で夷験群，奶照群の両者の間にはX線透過性に差は，認めら れなかった。

す。しかし，一部埋植窩底部に限り骨形成の非常に悪い ところがあり，埋植 3 日目で同部に血餅の存在が認めら れた。野上 ${ }^{511}$ は，血腫形成や多量の出液の眝溜などが 存在すれば，細胞の定着性が妨げられ，細胞分化に障害 を来すと述べている。をこで，人工歯根埋植にあたり十 分な止血が必要である。

また, Brunski ${ }^{29}$ は埋植直後から人工雪根化動摇が加 わった場合人工歯根と骨の間に線維性結合組織が介在 し，さらに動摇を助長し最終的には脱落したと述べてい， る. そこで，人工崡根理植初期の固定が重要で，人工齿 根の動摇は禁忌である．人工歯根と母床骨の界面に線維 性結合組織を介在させないことが，予後を大きく左右す
ると思われる．人工崡根の小突起部の母床骨に近接した 部位では，脱灰象牙質の厚さは 10〜20 $\mu \mathrm{m}$ 程度となり 匾された状態であり，スペース部では $100 \mu \mathrm{m}$ 程度の 厚さであり，眖厕象牙質は人工歯根に対してクッション の役割を果たし，人工歯根を保持する役目を十分に果た していた，そこで，骨誘導能を有し弾力性を有する眖戻 象牙質は人工歯根の初期固定に有用な称料と思われた。

今回は脱灭象牙質を埋植窝内に捚入し，そこに人工歯 根を埋植したが，その際脱灰象牙質のずれなどが生ずる 可能性がある，今後臨床応用にあたり，人工梅根と眖厕 象牙質を接着する必要がある。また顚骨，老人や母床 骨の骨梁が粗である場合に，人工歯根のみで用いるより 
も骨誘導能を有する材料との併用が，応用の幅を飛躍的 に広げる可能性もある。

本実験に用いた脱灰象牙質は埋植直前にあらかじめ抜

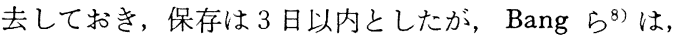
脱灰象牙質の骨誘導能の維持に関する研究で, 保存温度 が室温の場合 8 12 週で骨形成能は消失し, $-20^{\circ} \mathrm{C}$ と $4{ }^{\circ} \mathrm{C}$ では共に 52 週経過しても，50\% の脱灰象牙質に骨 誘導能があったと述べている。 また，脱灰処理による免 疫反応の消失は多くの研究者によって述べられてお $\eta^{52,53)}$, 保存法を確立することで, 同種他家, 異種象牙 質の応用や，自家象牙質の長期保存による dentin bank などの可能性を示唆している.

\section{V. 結}

\section{論}

1) 脱灰象牙質は非常に弾力性を持っており，脱灰象 牙質を併用することにより埋植時人工歯根の固定を良好 に保った。

2) 埋植 3 日目から脱灰象牙質周囲には類骨形成が促 され，3か月目で人工歯根のほほ全面が成熟骨で被わ れ，人工歯根と骨之の骨性瘾着は対照群上り早期泟開始 した。

3) 脱灰象牙質は, 吸収されながらさらに層板状の石 灰化が起こり骨と置き換わる。

稿を終えるにあたり，終始こ愁篤なるこ指導，こ校閲 を賜りました岩手医科大学齿学部口腔解剖学第 1 講座野 坂洋一郎教授に深甚なる謝意を表します。

さらに終始こ指導，こ鞭撻を戴きました岩手医科大学 菡学部口腔解剖学第 1 講座伊藤一三助教授 (現奥羽大学

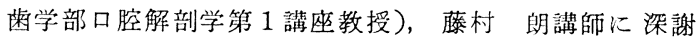
致します。

また，御協力戴きました教室員各位に厚く御礼申し上 げます。

な拉，本論文の要旨の一部は，第42回日本口腔外科学 会総会（昭和63年 6 月16日, 札幌), 第 31 回萪科基礎医 学会（平成元年 9 月 2 日，德島）に打いて発表した。

\section{引用 文 献}

1) Osborn, J.F. and Newesely, H.: Dynamic aspects of the implant-bone-interface. Dental Implants, Carl Hanser Verlag, 1980, p111-123.

2) 玉置敏夫, 川原春幸, 他: 安全度の高い局部骨 膜下インブラント。陮界展望 別冊インプラン トの臨床：215-226 1975.

3) Piecuch, J.F.: Extraskeletal implantation of a porous hydroxyapatite ceramics. J Dent Res 61: 1458-1460 1982.

4) 大西正俊：各種人工骨の特徵々現状。蔽科シ ーナル 25(2): 201-206 1987.
5) Urist, M.R., Iwata, H., et al.: Bone morphogenesis in implants of insoluble bone gelatin. Proc Natl Acad Sci USA 70: 351133151973.

6) Einhorn, T.A., Lane, J.M., et al.: The healing of segmental bone defects induced by demineralized bone Matrix. $\mathrm{J}$ bone Join Surg 66-A: 274-279 1984.

7) Urist, M.R., and Mikulski, A.: Solubilized and insolubilized bone morphogenetic protein. Proc Narl Acad Sci USA 76: 182818321979.

8) Bang, G., Johannessen, J.V., et al.: The effect of physical treatment on the induction of heterotopic bone formation by demineralized dentin in guinea pigs. J Oral Path 1: 231-243 1972.

9) Ashman, A.: The acrylic resin tooth implant. J Prosthet Dent 29: 549-555 1973.

10) Hodosh, M. and Shklar, G.: The porous viterous carbon polymethacrylate tooth implant; Preliminary studies. J Prosthed Dent 32: 326-334 1974.

11) Russell, W.B. and Royston, P.: Tissue reaction to acrylic resin. J Prosthet Dent 35: 156-159 1976.

12) Peterson, L.J. and Pannel, B.M.: Clinical radiographical and histological evaluation of porous rooted polymethylmethacrylate dental implant. J Dent Res 58: 489-496 1979.

13) Klawitter, J.J. and Weinstein, A.M.: Fabrication and characterization of porousrooted polymethylmethacrylate (PMMA) dental implants. J Dent Res 56: 385-393 1977.

14) Peterson, L.J. and Pennel, B.M.: Clinical and histological evaluation of porous rooted cobalt-chromium (Co-Cr) prosthetic teeth. J Dent Res 55: IADR Abstracts B 1961979.

15) Piliers, S.J., Schnitman, P., et al.: Histopathology of oral endosteal metallic implants in dogs. J Dent Res 52: 1117-1127 1973.

16) Albrektsson, A., Branemark, P.I., et al.: Oseointegrated titanium implant. Acta Orthop Scand 52: 155-170 1981.

17) Young, F.A., Kresch, C.H., et al.: Porous titanium tooth roots; Clinical evaluation. J Prosth 41: 561-565 1979.

18）山根稔夫：パイオラム, サファイア・インプ ラントの動物実験に上る臨床的考察。菌界展望 50: 1179-1184 1977.

19) Mckinney, R.V. Jr. and Koth, D.L.: The singlecrystal saphire endosteal dental implant material characteristics and 18 month ex- 
perimental animaltrials. J Prosthet Dent 47 : 69-84 1982.

20）中川貧一，桶出 誠，他：多孔質アルミナ七ラ ミックス・インプラントに関する夷験病理学的 研究。橉科学報 87: 1247-1261 1984.

21）田端恒雄：アバタイトセラミックインブラント の生物学的特性々臨休術式の検討。口病誌 54 : 8-14 1987.

22）田端恒夫, 小木曾誠：アパタイトセラミックイ ンプラントーその特徴と臨床の要点についてー Dental Diamond: 16-24 1986.

23) 石田光輔：アパタイトセラミックス，インプラ ントの骨組織による保持に関する組織学的研 究. 口病誌 51：333-371 1984.

24）嶋林三郎：ヒドロキシアパタイトと生体成分と の相互作用海関する物理化学的研究，薬学雑誌 107: 327-337 1987.

25) 小木曽誠：アバタイト表面に拈ける骨組織形成 ならびにその石灰化について，口病誌 50:1221983.

26) Hench, L.L. and Pachall, H.A.: Histochemical responses at a biomaterials interface. J Biomed Mater Res Symp 5: 49-64 1974.

27) Linkow, L.I., Chercheve, R. et al.: Theory and techniques of oral implantology. Vol. 1, Mosby, Saint Louis, 1970, p 81-133.

28) 石木哲夫・歯科インプラントを取り巻く病理学 的諸問題。歯科シャーナル 18: 273-279 1983.

29) Brunski, J.B., Moccia, A.F. Jr., et al.: The influence of functional use of endoseous dental implants on the tissue-implant interface. J Dent Res 58: 1970-1980 1979.

30) Branemark, P.I.: Oseointegrated titanium implants in the rehabilitation of the edentulous patient. Adv Biomat 4: 133-141 1982.

31) Huggins, C.B.: Influence of urinary tract mucosa on the experimental formation of bone. Proc Soc Exp Biol Med 27: 349-351 1930.

32) Reddi, A.H., Winston, A., et al.: Collagenous bone matrix-induced endochodral ossification and hemopoiesis. J Cell Bio 69: 557-572 1976.

33) Forley, J.R. and Baylink, D.J.: Purification of a skeletal growth factor from human bone. Biochemistry 21: 3502-3507 1982.

34）大山治：牛脱灰骨由来形成因子に関する实験 的研究. 東北大学歯学雑誌 4: 123-134 1985.

35) Takaoka, K., Ono, K., et al.: Solubilization and concentration of a bone-inducing substance from a murine osteosarcoma. Clin Orthop and Rel Res 148: 274-280 1980.

36) Hanamura, H., Higuchi, Y., et al.: Solubilized bone morphogenetic protein (BMP) from mouse osteosarcoma and rat demineralized bone matrix. Clin Orthop and Rel Res 148: 281-290 1980.

37) Sato, K. and Urist, M.R.: Induced regeneration of Calvalia by bone morphogeneitic protein (BMP) in dogs. Clin Orthop and Rel Res 197: 301-311 1985.

38) Howes, R., Bowness, J.M., et al.: Plateletderived growth factor enhances demineralized bone matrix-induced cartilage and formation. Calcif Tissue Int 42: 34-38 1988.

39）中原治彦，高岡邦夫：骨形成因子の臨床応用の 可能性一骨誘導能を有する生体材料の開発一. 形成外科 30: 535-542 1987.

40) Inoue, T., Deporter, D.A., et al.: Induction of cartilage and bone by dentin demineralized in citric acid. J Perio Res 21: 243-255 1986.

41) Inoue, T., Deporter, D.A., et al.. Induction of chondrogenesis in muscle, skin, bone marrow, and periodontal ligament by demineralized dentin and bone matrix in vivo and in vitro. J Dent Res 65: 12-22 1986.

42) Catanzaro, S.A., Catanzaro, P.N., et al.: Osteogenic potential of autogenic demineralized dentin implanted in bony defects in dogs. Int J Oral Maxillofac Surg 15: 1601691986.

43）矢作 茂：脱灭処理象牙質移植による軟骨扣よ び骨形成能に関する実験的研究，歯科学報 85 : 135-165 1985.

44）井上 孝, 下野正基, 他 : インプラントと歯根 膜. 歯界展望 67: 1027-1037 1986.

45）遠藤哲彦, 藤村 朗, 他：脱灰象牙質による骨 形成能に関する形熊学的研究. 解剖学雑誌 62 : 6741987.

46) Bassett, C.A.: Current concept of bone formation. J Bone Joint Surg 44: 1217-1244 1962.

47) Urist, M.R. and Hudak, R.T.: Radioimmunoassay of bone morphogenetic protein in serum: a tissue-specific parameter bone metabolism. Proc Soc Exp Biol Med 176: 4724751984.

48) Urist, M.R., Huo, Y.K., et al.: Purification of bovine bone morphogenetic protein by hydroxyapatite chromatography. Proc Natl Sci USA 81: 371-375 1984.

49）鴨原隆：牛骨由来形成因子に関する実験的研 究一高速液体クロマトグラフを用いた部分精製 について一。東北大料誌 5：75-86 1986.

50) Price, P.A., Urist, M.R., et al.: Matrix gla-protein a new-carboxy-glutamic acid-containing protein which is associated with the organic matrix of bone. Biochem Biophys 
Res Commun 117: 767-771 1983.

51）野上宏, 大平敦彦：骨誘道について。 日整 外 14: 1073-1079 1979.

52）小澤 隆，系满盛憲：同種処理骨の抗原性に関 寸る実験的研究一冷凍骨, 冷凍脱骨髄骨, 凍結
乾燥骨, 脱灰骨の比較一. 北里医学 11: 4824941981.

53) 相沢 幹: 移植骨と移植免疫. 日病理誌 62 : 69-98 1973. 